Tkacova, H. (2021). Intolerance across generations: the relation of the Slovak majority to the Jewish minority before, during and after the fall of the communist regime (selected aspects). Ethnic problems of the era of globalization. Collection of Scientific Articles. European Scientific e-Journal, 3 (9), 25-39. Hlučín-Bobrovníky: "Anisiia Tomanek" OSVČ

Tkáčová, H. (2021). Netolerancia naprieč generáciám: Vzt’ah slovenskej majority k židovskej menšine pred, počas a po páde komunistického režimu (vybrané aspekty). Ethnic problems of the era of globalization. Collection of Scientific Articles. European Scientific e-Journal, 3 (9), 25-39. Hlučín-Bobrovníky: “Anisiia Tomanek” OSVČ.

DOI: $10.47451 /$ eth2021-01-001

The paper will be published in Crossref, ICI Copernicus, Academic Resource Index ResearchBib, J-Gate, ISI International Scientific Indexing, Zenodo, OpenAIRE, BASE, LORY, LUASA, ADL, eLibrary, and WebArchive databases.

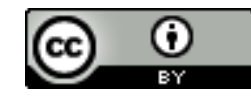

PhDr ThDr Hedviga Tkáčová, PhD, Assistant Professor, Faculty of Humanities, University of Žilina. Zilina, Slovakia. ORCID: 0000-0003-3062-2284.

\title{
Intolerance across generations: the relation of the Slovak majority to the Jewish minority before, during and after the fall of the communist regime (selected aspects) \\ (in Slovak)
}

Abstract: The paper presents the theoretical basis of the issue of existence and application of intolerant attitudes of the majority population in relation to the minority Jewish community in Slovakia. We focus primarily on selected aspects of intolerance against Jews - specifically Slovak nationalism (i.e., political clericalism) and Jewish antisemitism. The starting point of the article is quantitative and qualitative research of Slovaks' attitudes in the past, in which several experts revealed a negative stereotypical and negative perception of "difference", which is understood as "not Slovak", event. not "ours". We point out that the given attitude extends across generations and across periods (before communism, during it and after communism, i.e., to the present). Subsequently, the text presents the observations that emerged from the survey itself. The aim of the qualitative survey was to describe and analyse the opinions and attitudes of respondents in relation to Jews in Slovakia.

Keywords: intolerance, Jews, Slovaks, attitudes, communism, research, personal experience.

PhDr ThDr Hedviga Tkáčová, PhD, Assistant Professor, Katedra filozofie a religionistiky, Fakulta humanitných vied, Žilinská univerzita v Žiline. Žilina, Slovakia. ORCID ID: 0000-0003-3062-2284.

\section{Netolerancia naprieč generáciám: Vzt’ah slovenskej majority k židovskej menšine pred, počas a po páde komunistického režimu (vybrané aspekty)}

Abstrakt: Príspevok predstavuje teoretické východiská problematiky existencie a uplatňovania netolerantných postojov majoritného obyvatel'stva vo vzt’ahu k minoritnej židovskej obci na Slovensku. Sústredíme sa predovšetkým na vybrané aspekty netolerancie voči Židom - špecificky slovenský nacionalizmus (t. j. politický klerikalizmus) a antisemitizmus. Východiskom príspevku sú v minulosti realizované kvantitatívne aj kvalitatívne výskumy postojových orientácii Slovákov, v ktorých viacerí odborníci odhalili negatívne stereotypné a odmietavé vnímanie "odlišnosti”, ktorá je chápaná ako "nie slovenská", event. nie "naša". Poukazujeme nato, že daný postoj sa tiahne naprieč generáciám a naprieč obdobiami (pred komunizmom, počas neho aj po komunizme, t.j. do súčasnosti). V nadväznosti nato text predkladá pozorovania, ktoré vzišli v rámci vlastného prieskumu. Cielom kvalitatívneho prieskumu bol popis a analýza názorov a postojov respondentov vo vzt’ahu k Židom na Slovensku. 
Kl’úcové slová: netolerancia, Židia, Slováci, postoje, komunizmus, prieskum, osobná skúsenost’.

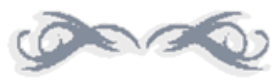

\section{Úvod}

Medzinárodná legitimita moci komunistických strán vo východnej Európe vychádzala z výsledkov druhej svetovej vojny - z porážky nacizmu a vít’azstva komunizmu. Vychádzajúc zo záverov Jaltskej konferencie (a na nej ustanovených dohôd z februára 1945) sa na pozadí studenej vojny 'slobodný západný svet živil antikomunizmom a 'komunistický východný svet' zase antiimperializmom a antikapitalizmom. Oba ideologické tábory vyhlasovali, že sú v radikálnom konflikte a len máločo, ak vôbec niečo, majú spoločné. Slováci tento súboj vnímali predovšetkým ako súbor hodnôt. Naviac, v postoji k Židom boli Slováci reprezentantmi východného bloku a jeho ideí, zatial' čo Židia boli príslušníkmi 'nepriatel’ského bloku'.

Po dlhé desat'ročia ostával imerializmus a kapitalizmus, v mysli Slovákov obrovským nepriatel'om komunistických 'hesiel' o spoločnej del'be práce, socialiżme s l'udskou tvárou, spoločnom vlastníctve výrobných prostriedkov a pod. Pravdou je, že stále existuje mnoho tých, ktorí za komunizmom smútia, hlásiac zlyhanie demokracie, ktorá sl’ubovala harmonické spolunažívanie, toleranciu, náboženskú slobodu, dialóg, otvorenost' a napredovanie. Vel'ké očakávania sa nenaplnili. Nepodarilo sa uskutočnit' 'harmóniu' tam, kde sú prítomné relatívne pravdy a hodnoty. A tak nám, slovami Hrehovej, nielen dejinná ale aj súčasná skúsenost' ukazuje, že v perspektíve každodennej morálnosti, od ktorej závisia medzil'udské vzt’ahy aj vzt’ahy medzi rôznymi kultúrami a náboženstvami (či samotný l’udský život), nie je relativita možná (Hrehová, 1990). Vyúst'uje do l’ahostajných postojov a tým o.i. podporuje aj netoleranciu, xenofóbiu, agresiu a rasizmus.

\section{Slováci a netolerancia vo svetle relevantných výskumov}

Uvažujúc o negatívnych postojoch Slovákov voči Židom v kontexte posledných generácií, predstavuje zaujímavý názor Vago. Autor je presvedčený, že to boli predovšetkým postkomunistické zmeny, ktoré sa hlboko dotkli Slovákov, a to na citlivom mieste - v slovenských rodinách. Podl’a autora sa rodiny po páde komunizmu stali nositel'mi predstavy o "večnom prefíkanom Židovi”, ktorý riadi krajinu aj svet. Pozadie tohto názoru vysvetl'uje autor nasledovne. Mnohých vysokopostavených funkcionárov počas komunizmu, ktorí boli Židmi, striedali v nových vedúcich pozíciách po roku 1989 ich deti. Antisemitizmus hovoril o otcoch, ktorí “privodili komunistický teror” a o det'och, ktoré už 'obrodené a demokratické' pokračujú "konštituovaním postkomunistickej elity”, ovládajúc ekonomiku a médiá; k Protokolom sionských mudrcov sa pridáva 'generačný prídavok', t.j. Protokol sionskej mládě̌ze. Osud detí nežidovských funkcionárov z čias komunizmu sa samozrejme nespomína, aby sa nenarušil stereotyp (Vago, 2000).

V kontexte akéhosi 'dedičstva' postojov majority voči kultúrne, nábožensky a inak diverzným skupinám existujú na Slovensku ale i také štúdie, ktoré takéto generačné dedičstvo nepotvrdzujú či ho dokonca vyvracajú. Jednou z takýchto štúdií je kvantitatívny výskum autora Jána Vlacha, ktorý sa venoval prenosu hodnôt z rodičov na ich vysokoškolskú mládež a 
prostredníctvom výskumu potvrdil výrazné rozdiely v preferenciách jednotlivých hodnôt medzi populáciami detí (aj v závislosti od pohlavia) a rodičov. Mládež má väčší záujem o altruistické hodnoty voči druhým a o vzt’ah k svojmu okoliu (prírode a spoločnosti). Vysokoškoláci so svojimi rodičmi nezdiel'ajú ani konzervatívne hodnoty, ktoré sú u rodičov výrazné (Vlach, 2006). Príklon skúmaných vysokoškolákov k altruistickým hodnotám považujeme za pozitívne, nakol'ko altruistické správanie dáva dôraz na obojstranné obohacovanie, čo je základným predpokladom aj pre mierovú existenciu náboženstiev, medzináboženský dialóg a pod.

Kdesi na pomedzí oboch autorov stojí zahraničná štúdia Ronalda Ingleharta a Wayne Bakera, ktorí si všímajú żmeny v spoločnosti v čase, kedy jedna generácia strieda druhú. Ak sa spoločnost' napríklad rozvija a ekonomicky silnie, podl'a autora postupuje smerom k demokracii a rešpektu l’udských práv, pričom sa odkláňa od tradičných hodnôt zameraných na konzerváciu súčasného stavu. Spoločnost' sa mení nie preto, lebo sa zmenili hodnotové systémy v generácii, resp. prevládli názory a vplyv staršej generácie na mladšiu, t.j. vplyv rodičov na deti. Spoločnost' sa mení preto, lebo sa medzičasom vymenili l’udia; t.j. staršiu generáciu vystriedala mladšia. Podstatné však je, že hodnoty v oboch generáciách ostávajú podl’a autorov štúdie pomerne stabilné (Inglehart \& Baker, 2001). To opät’ potvrdzuje generačný vplyv (aj v otázkach netolerancie).

Naviac, v tomto kontexte upozorňuje Kvasničková, že ak je minulost' jednej generácie sporná alebo nedoriešená, potom sa nevyriešené problémy nanovo vracajú a v obnovovaných aj nových kontextoch vytvárajú priestor na netoleranciu (Kvasničková, 2005). Dochádza k prestupu netolerantných postojov, stereotypov aj predsudkov z generácie na generáciu, a to má podl’a autorky nie raz dokonca stúpajúci charakter. Okrem iných tak aj napr. Vašečka predstavuje generačný vplyv ako neodmyslitel’nú základňu pre vznik neznášanlivých postojov. Autor vyslovuje príklad, v ktorom uvádza, že vel'ká čast' mladých l’udí žijúcich v časoch vojnového Slovenského štátu a v období po ňom vytvorila svoju generačnú spolupatričnost' nielen spoločným prežívaním obdobia Slovenského štátu, ale aj rovnakými (t.j. netolerantnými) postojmi voči Židom. Tieto postoje sa stali stavebnými tehličkami ich generačnej identity; teória obdobne platí pre všetky generácie (Vašečkea, 2013).

Spomedzi mnohých odborníkov hodnotí vnímanie 'odlišnosti' u Slovákov v súčasnosti už spomínaný Vašečka, ktorý uvádza, že Slovensko sa bráni cudżím prvkom a chce mat' všetkých podobných sebe. Podl’a Vašečku sú menšiny na Slovensku objektom tzv. rasistickébo paradoxu zo strany väčšinovej spoločnosti; majorita ich síce vyzýva $\mathrm{k}$ integrácii, no táto ponuka sa $\mathrm{v}$ spoločenskom a mediálnom diskurze vyznačuje asimilačnými tlakmi - majorita chce mat' všetkých na svoj obraz.

Na vysokú mieru netolerantnosti a (neprijatel'nej) sociálnej vzdialenosti Slovákov vo vzt’ahu k menšinám (predovšetkým voči Židom, Arabom, černochom a Rómom, pozn.) opakovane poukazujú závery eurobarometrov (TASR, 2018; Redakcia Aktuality.sk, 2016). Obdobné zistenia prinášajú aj d’alší odborníci, ktorí sa zhodujú na tom, že medzi Slovákmi je prítomný výrazný odpor voči religiózne a etnicky diverzným skupinám; v kontexte religiozity voči moslimom a Židom; z pohladu etnicity najmä voči Rómom (Macháček, 2007; Gallová-Kriglerová et al., 2009; Chudřçeová, 2011; Polonský \& Novotný, 2011; Krivý, 2001; Kamenec, 2005; Hargašová, 1995). Napokon aj podl’a Inštitútu pre verejné otázky preukazujú bežní Slováci viditel’ne kritický postoj a 
vysoký sociálny dištanc voči akejkol'vek 'odlišnnosti', a to aj na personálnej úrovni (Inštitút pre verejné otázl.y, 2017).

Stručne, o netolerancii majority voči židovskej minorite možno hovorit' aj ako o dôsledku generačného vplyvu, čo potvrdzujú aj výskumy. Tie pripomínajú, že ak je minulost' jednej generácie sporná alebo nedoriešená, potom sa nevyriešené problémy nanovo vracajú a $v$ obnovovaných aj nových kontextoch vytvárajú priestor na netoleranciu. Otázkou ostáva, aké oblasti sú pre slovenskú verejnost' vo vzt'ahu k židovskej menšine nevyriešené a pod zdanlivým tichom čakajú na svoj návrat. Je nenávistný postoj k Židom v našich kultúrnych, náboženských, sociálnych a d’alších kontextoch už nadobro ukončený, alebo máme očakávat' jeho renesanciu?

\section{Vzt'ah slovenskej majority $\mathrm{k}$ židovskej menšine pred komunizmom}

Hradská poukazuje na komunitu Židov ako na sprvoti utláčanú a zakríknutú menšinu, ktorá v 19. storočí zažíva hospodársku prosperitu aby sa napokon stala "obetným baránkom", zodpovedným za všetky neduhy a problémy vtedajšej slovenskej spoločnosti. Podla Hradskej sa slovo "Žid” medzi Slovákmi už v 19. storočí (a d’alej) stotožňovalo so slovom úžerník. Prevažovali tendencie hladiet’ na Židov cez prizmu ich majetkového postavenia v spoločnosti; negatívne vášne vzbudzovala hospodárska moc Židov a ich hospodárska expanzia. K stereotypizácii Židov na Slovensku prispelo aj presvedčenie väčšiny o tom, že Židia udávali Slovákov, rozširovali neslovenskú tlač, nadŕžali Mad’arom (t.j. boli považovaní za organickú súčast' mad’arského židovstva) a budili medzi Mad'armi nenávist' voči slovenskej vláde aj voči národu (Hradská, 2014). Krekovičová a Panczová dodávajú, že názor majority, že Židia sa usilujú byt' oporou mad’arským politickým, kultúrnym a hospodárskym elitám ich staval do pozície "nepriatelov slovenského nacionalizmu" (Krekovičová \&o Panczová, 2013).

Mešt'an taktiež pripomína špecifickú podmienku šírenia nacionalizmu a židovského antisemitizmu na Slovensku v období pred komunizmom. Poukazuje na politický klerikalizmus niektorých katolíckych cirkevných predstavitelov (vrátane prezidenta štátu), v období počas druhej svetovej vojny. Za politickým klerikalizmom, ktorý sa na Slovensku ukazuje naprieč generáciám, stojí prípad slovenského prezidenta a katolíckeho kňaza Jozefa Tisa, ktorý bol odsúdený za vlastizradu a popravený; do svojej smrti odmietal odsúdit' zločiny nacistického Nemecka, vrátane idey koncentračných táborov.

Dodajme, že po skončení Druhej svetovej vojny žilo na Slovensku (t.j. v obnovenom Československu), napriek smutne známym dôsledkom 'riešenia' židovskej otázky ešte stále približne 30 tisíc Židov (Klein-Pejšová, [online]).

Stručne, hospodársku prosperitu Židov koncom 19. a v prvej polovici 20. storočia strieda tiaž prenesenej zodpovednosti za všetky neduhy a problémy vtedajšej slovenskej spoločnosti. Židia boli tými, ktorí mali vždy vel’ké zásoby. Vyčítalo sa im, že udávali Slovákov, rozširovali neslovenskú tlač, nadŕžali Mad’arom a pod. Aj prax potvrdzovala, že na Slovensku žili ako cudzinci, t. j. od Slovákov iní a odlišní - jazykovo, hospodársky aj nábožensky. $\mathrm{V}$ očiach majority sa sčasti pravdivo, sčasti ako dôsledok prepracovanej propagandy, formoval nelichotivý obraz Žida ako úžerníka, obchodníka, krčmára, okrádača, mudrlanta, špekulanta a predovšetkým vykorist'ovatel'a. Napriek každodenným prejavom 
netolerancie a režimovým opatreniam ostáva na Slovensku po vojne približne 30 tisíc Židov.

\section{Vzt'ah slovenskej majority k židovskej menšine počas komunizmu}

Okrem nacionalizmu a antisemitizmu, ktoré na Slovensku reprezentoval politický klerikalizmus a jeho otvorená podpora nemeckej Tretej ríše, to bol predovšetkým komunistický režim, ktorý prispel k definitívnemu odchodu vojnu preživších Židov zo Slovenska do cudziny (a k malému počtu Židov na Slovensku v súčasnosti; cca 3 tisíc).

Po nástupe komunistickej strany v roku 1948 bolo jedným z prvých opatrení štátne obmedzenie práva občanov na slobodu vierovyznania. Až dnes vidíme, že toto ústavné právo bolo zo strany komunistov významne porušované a nerešpektované až do konca diktatúry $\mathrm{v}$ roku 1989. Za čias najsilnejšieho komunizmu dochádzalo až k viditel’nému útlaku a k deklarovanej neslobode v otázke náboženského vierovyznania. Komunizmus sa, slovami Budila, stal “vážnou krest’anskou herézou” (Budil, 2006).

Život krest’anov pulzoval d’alej - usídlený a koncentrovaný v podzemných štruktúrach tzv. Tajnej cirkvi. Očividne ale na Slovensku v danom období absentovali akékol'vek iné svetové náboženstvá, vrátane judaizmu, rovnako ako nové náboženské hnutia; hoci, slovami Orbanovej, mali v iných Európskych krajinách už vytvorené svoje pevné štruktúry a spoločenské zázemie (Orbanová, 2009).

Pretrvávanie nacionalistických, rasových a antisemitských nálad v myslení časti obyvatel'stva na Slovensku pretrvávalo aj v období komunizmu. Podl'a Mešt'ana nato mali vplyv predovšetkým dva faktory. Bola to asimilačná politika komunistického režimu vo vzt’ahu k menšinám (i Židom) a už vyššie spomínané a stále živé obviňovanie Židov z účasti na mad’arizácii Slovákov (Meštan, 2000). Asimilačná politika bola postavená na zásadnom popieraní protižidovských zásahov zo strany štátu, vrátane popierania existencie antisemitizmu. Komunisti dali netolerancii, namierenej proti Židom na Slovensku 'novú' podobu - stáli v nikdy nepriznanej, a predsa zjavnej a otvorenej opozícii voči antisionizmu a štátu Izrael.

Povedané stručne, v období komunizmu dochádza vo vzt'ahu majority a Židov na Slovensku k prehlasovaniu myšlienok nacionalizmu a antisemitizmu. Tie podporoval aj štát: vo vojenskom období hlásal tzv. politický klerikalizmus a po vojne ideológiu komunizmu. Predovšetkým komunizmus ale prispel k definitívnemu odchodu Židov zo Slovenska, nakol'ko komunisti ohrozili aj právo občanov na slobodu vierovyznania. Židia stratili poslednú nádej na slobodný a pokojný život, ktorého súčast'ou je aj náboženstvo. Na Slovensku v danom období úplne chýbali iné náboženstvá; nehovoriac už o medzináboženských aktivitách a vzt'ahoch. V štyridsat' ročnom období komunistickej totality pretrváva podl’a odborníkov najmä obviňovanie Židov z účasti na mad’arizácii Slovákov. Obvinenia plne podporuje (aj) voči Židom sústredená asimilačná politika komunistického režimu.

\section{Vzt'ah slovenskej majority $\mathrm{k}$ židovskej menšine po komunizme}

$\mathrm{Na}$ šírenie nami sledovaných aspektov - nacionalizmu a antisemitizmu na Slovensku nadviazali politici aj po r. 1990. V prístupe k Židom sa, krátko po páde komunizmu, začalo aktivizovat' viacero skupín pravicových radikálov (tie mali prepojenie na medzinárodnú siet' 
extrémistických hnutî). Charakterizoval ich negacionizmus, revizionizmus, osvienčimská lož a d’alšie javy, namierené proti Židom či spochybňujúce zločiny holokaustu.

Nežná revolúcia otvorila nielen hranice; s pádom berlínskeho múru sa skončilo delenie sveta na východný a západný blok a tzv. Nežná revolúcia priniesla Slovákom odstránenie komunistického režimu tzv. 'nekrvavým spôsobom'. Bola to revolúcia, ktorá po páde komunizmu otvorila aj politický priestor, ktorý umožnil vzniku viacerých neol’udáckych strán. S nimi ožila aj obhajoba fašizmu, čo možno vidiet' pri pohl’ade na výroky zo zakázaného samizdatu - predovšetkým vysvetl'ovanie fašizmu ako obrannej ideológie pred ovládaním a rozpínavost'ou židovstva. Ak sa chcelo Slovensko ubránit' pred touto hrozbou, malo sa (podl'a 'demokratických fašistov') uchýlit' k nacionalizmu (Hlas Slovenska, 1988, 1991 a d'alšie).

Etablovanie pravicových radikálnych hnutí v slovenskej spoločnosti bolo podl’a Hradskej založené na požiadavke rasovej čistoty. Dodnes v nich podl'a autorky ide o cielenú podporu neznášanlivosti a otvorený antisemitizmus, ktorý označuje judaizmus za kacirsky hebrejizmus a Židov za antikeristov a klamárov. Židom sú zároveň prisudzované snahy o svetovú nadvládu a ciele svetového miešania rás či zničenia pravého krest’anstva (Hradská, 2007).

G. Fatranová (2000) sa v kontexte po komunistického diania rozhodla skúmat’ štyri hlavné antisemitské javy, ktoré boli medzi Slovákmi v skrytosti vždy prítomné, ale nanovo ožili najmä po páde komunistického režimu. Zaujímalo ju, do akej miery antisemitské javy čerpajú z minulosti, čo medzi Slovákmi ovplyvňuje ich efektívnost' a či dochádza aj k ich odumieraniu. Podl'a autorky sa krátkodobo a marginálne ukazovala nenávist’ voči Židom v dôsledku:

a) presvedčenia Slovákov o svetovládnych úmysloch Židov,

b) názoru, že Židia Slovákov zdierajú a okrádajú,

c) obvinení Židov z účasti na mad’arizácii Slovákov.

Podl’a Fatranovej iba jeden jav pretrváva do súčasnosti - opät’ ide o rovnaký jav - slovenský nacionalizmus (ktorý sa naplno rozvinul vd’aka politickému klerikalizmu počas druhej svetovej vojny a ktorý, zdá sa, pretrváva) (Fatranová, 2000).

Výskum Fatranovej potvrdil, že kauza Tiso stále vzbudzuje staronové emócie, nakol'ko sa stala nielen oblúbeným výkrikom antisemitov, ale o.i. aj dozvukom úsilia o uznanie existencie slovenskej štátnosti. Širšie to objasňuje aj František Mikloško, disident za čias komunizmu a aktivista vtedajšej tzv. Tajnej cirkvi. Podl’a Mikloška je Tisova poprava po vojne stále slovenskou traumou. "Bol to kňaz a obesit' kňaza je potupná smrt', ktorá sa l’udí hlboko dotýka." To z neho urobilo mučeníka a tak sa "na jeho poprave d’alej šírila myšlienka slovenskej štátnosti” (V agovič, 2012).

Aj v súčasnosti je postoj Slovákov k židovskej menšine špecifický. Vago hovorí o.i. o tzv. očistovaní histórie, t.j. v prekrúcaní minulosti alebo v udržiavaní presvedčenia, že osud Židov sa počas vojnového Slovenska nijako nelišil od osudu obyčajných Slovákov alebo iných menšín. Ďalším negatívnym javom postkomunistickej doby je podl'a autora systematický útok na historickú pamät' holokaustu s ciel'om relativiz̧ovat holokaust. Vago pripomína aj dôsledky nárokov Židov na reštitúcie a odškodnenie, ked’ hovorí o spôsoboch, ako sa tieto nároky prezentujú verejnosti. Argumentácia je postavená tak, aby bolo verejnosti jasné, že ide o "židovský pokus vytĺkat' peniaze od postkomunistických štátov" (Vago, 2000). Daný spôsob chápu Slováci ako “vykorist'ovanie", čo sa prejavuje ako vel'ká 'nevôl'a' majority voči židovskej komunite ako celku. 
Vago a d’alší, vyššie predstavení autori, predstavujú nenávist' voči Židom a antisemitizmus ako dôsledok generačného vplyvu, ktorý sa naplno prejavil práve po komunizme. Ako sme naznačili vyššie v texte, podl’a Vaga sa však postkomunistické zmeny hlboko dotkli najmä rodinných spoločenstiev. V obyčajných slovenských rodinách nabral totiž antisemitizmus jeden zo svojich najsilnejších argumentov - vd'aka rodine a v rodine vznikol stereotyp o "večnom prefíkanom Židovi, ktorý riadi krajinu” (V ago, 2000).

Častý a oblúbený nový antisemitský slovník nikdy neopomína ani pojem globaliqácia. Práve naopak, globalizáciu spája so záujmami súčasného tzv. svetového židovstva. Moderný antisemitizmus identifikuje Židov, slovami Vaga, ako prvotných šíritel’ov globalizácie aj ako jej blavných ư̌ivatelov. Vd’aka globalizácii naberá stereotypný obraz Žida v očiach nežidov d’alšie nelichotivé charakteristiky - ide "o toho istého, večne prefíkaného a mazaného Žida, ktorý nemá korene a slúži svojim záujmom rozprestretým po celom svete” (Vago, 2000).

Krátke zhrnutie: Možno povedat', že aj v období po páde komunistického režimu dva nami sledované aspekty - slovenský nacionalizmus a židovský antisemitizmus - neustávajú. Na myšlienky politickébo klerikaliżmu nadviazali politici aj po r. 1990. Ich prejavom naviac sekundovali pravicoví radikáli, ktorí s využitím médií a nových médií prehlasovali myšlienky negacionizmu, revizionizmu, osvienčimskú lož a d’alšie javy, namierené proti Židom. Výnimkou neboli ani útoky na židovské kultúrne dedičstvo alebo spochybňovanie zločinov holokaustu. Nedávne výskumy potvrdili, že kauæa Tiso, resp. slovenský nacionalizmus stále vzbudzuje emócie, ktoré vedú k netolerancii. Ide o jeden zo spoločenských 'motivátorov', ktoré robia postoj Slovákov k židovskej menšine aj dnes špecifickým. Za charakteristické prejavy majority voči Židom po páde komunizmu možno považovat': tæv. očistovanie histórie; prekrúcanie minulosti, pokusy o rehabilitáciu a legitimizáciu odsúdených fašistických lídrov; útoky na bistorickú pamät' a kultúrne dedičstvo, pokusy o relativiqáciu holokaustu či úsilie extrémistov interpretovat právoplatné reštitúcie a odškodnenie Židov ako ich úsilie okeradnút' a żničit' slovenskú väčsinu. Slovenský nacionalizmus a stále živý antisemitizmus sa predovšetkým po páde komunizmu javí ako dôsledok generačného vplyvu. V obyčajných slovenských rodinách vzniká a naberá na sile jeden z najsilnejších argumentov proti Židom: Žid je večne prefíkaný a robi v̌̌etko preto, aby riadil a ovládal túto krajinu. V 21. storočí sa v prístupe $\mathrm{k}$ Židom v slovenských podmienkach aktivizuje viacero skupín pravicových radikálov. Tí označujú Židov ako prvotných šíritel’ov globalizácie aj ako jej blavných uživatelov. Globalizácia je v očiach extrémistov výmysel Židov, ktorí chcú nad’alej hájit’svoje qáujmy, roąprestreté po celom svete.

\section{Metodológia kvalitatívneho prieskumu}

Prieskum postojov respondentov voči Židom na Slovensku bol uskutočnený formou dvoch skupinových rozhovorov. Tie boli realizované začiatkom roka 2020. Plánovaný prieskum v tretej a štvrtej skupine (v ktorých mala pribudnút' aj výskumná kategória poblavie respondentov a interpretácia zistení na základe pohlavia respondentov) bol odvolaný vzhl’adom na nepriaznivú pandemickú situáciu COVID-19.

Prvú skupinu tvorili ôsmi respondenti oboch pohlaví so stredoškolským vzdelaním vo veku 18-40 rokov (1sk). Druhú skupinu tvorili ôsmi respondenti oboch pohlaví s vysokoškolským vzdelaním vo veku 18-40 rokov. Kriteriálny výber členov oboch výskumných skupín znázorňuje (Tabulkea 1). 
Ciel’om kvalitatívneho prieskumu bolo získanie názorov a postojov respondentov voči Židom, žijúcim na Slovensku. Výskumnou metódou bol skupinový roz̧̧ovor, ktorý bol realizovaný samostatne v každej výskumnej skupine.

V rámci prieskumu boli stanovené závery. Členovia oboch samostatne posudzovaných výskumných skupín vyjadrili vo vzt’ahu k zisteniam svoj súblas. Súhlas respondentov so zisteniami a závermi prieskumu boli našim osobným cielom; chceli sme čo najviac eliminovat' vlastné zásahy a vlastnú interpretáciu získaných výrokov v rámci oboch výskumných skupín.

\section{Zistenia prieskumu a diskusia}

Diskusia v každej zo skupín prebiehala v rozsahu dvoch hodín. Spočiatku zaznievali monotematické odpovede a zaznamenávali sme skôr všeobecný kontext vnímania odlišnosti židov v porovnaní s majoritnými Slovákmi. Postupne, s prehíbením vzájomných vzt’ahov sa medzi respondentmi objavili aj otvorene negatívne názory. S prvkami predsudkov a stereotypov zazneli názory, v ktorých respondenti hodnotili fyziognomické odlišnosti židov. Židom boli d’alej pripisované negatívne vlastnosti, ktoré respondenti spájali s náboženskou praxou. Názory, ktoré môžeme klasifikovat' ako predsudky a stereotypy vzišli v diskusii aj v súvislosti s predstavami respondentov o chamtivosti a lakomstve židov či ich úmysloch ovládat' svetové dianie (a médiá).

Zaujímavost'ou je, že hoci postoj respondentov oboch výskumných skupín sprevádzal väčšinový negativizmus, tento jav ustupoval potom, čo respondenti spomenuli osobnú skúsenost' so stretnutia so židom. Táto skúsenost' bola hodnotená pozitívne a zmienka o “peknom zážitku” mala vplyv aj na úsilie respondentov odvrátit’ negatívne postoje.

Z rozhovorov s respondentmi vyplynuli tieto pozorovania (respondenti súhlasili s takouto formuláciou zistení, pozn.):

1. Vôbec prvá, bezprostredná asociácia spojená so slovom 'Žid' sa u väčšiny respondentov spája s tým, čo je pre Slováka "cudzie", "fyziognomicky odlišné” a "iné”. Takéto vnímanie môže byt' (ale aj nemusî) dôvodom negatívnych názorov, ale aj postojov a skutkov, ktoré predstavitelia majority na Slovensku vykazujú vo vzt’ahu k židovskej menšine.

2. V dvoch skupinových rozhovoroch zaznievajú viaceré príklady rozdielnych a nie práve pochopených židovských sviatkov a zvykov, upravujúcich napríklad židovské princípy stravovania. Výraznejšie negatívne postoje zaznamenávame i v názore respondentov na židovskú kultúru; napr. obriezka malých chlapcov. Výnimkou je pozitívne hodnotenie židovskej hudby.

3. Najviac negatívne bol hodnotený vzhl’ad Židov. Respondentom prekážajú “copiky”. Sú presvedčení o "zlej bygiene" a Židov hodnotia ako "škaredých" a "nesympatických".

4. Respondenti v oboch skupinách konštatovali, že je to náboženská odlišnost' Židov (t.j. “Výraz̧né náboženské oblečenie a náboženské quyky”), ktorá ich robí “sociálne neatraktivnych”. Podl'a predsedu Ústrednébo zuäzu Židovských náboženských obcí P. Salnera alebo na základe výskumu T. Gyárfášovej je na Slovensku pritom v súčasnosti už väčšina takých mladých židov, ktorí sú otvorene sekularizovaní a prejavujú záujem skôr o židovskú kultúru a tradície ako o náboženstvo (Gyárfášová, 2008). Slováci sa v súčasnosti stretávajú s rovesníkmi, ktorí židovstvo považujú skôr za kultúrnu záležitost'. Netolerantný pohlad na Židov má, 
domnievame sa, korene inde, nakol'ko sa prípadný negativizmus Slovákov voči Židom nemôže odvolávat' na 'náboženský prvok'.

5. Podl’a respondentov je reakcia na verbálne prejavovanú intoleranciu voči Židom na verejnosti (napríklad v školskom prostredí, na vlakovej stanici alebo v hypermarkete) skôr výnimkou. Ak sa niečo také na verejnosti deje podl'a jedného z respondentov to "nik nekritizuje a nik to neodsúdi. Antisemitizmus sa v drvivej vä̌šine pripadov ticho toleruje”.

Záverom, môžeme vidiet', že vzt'ahy Židov so slovenskou majoritou majú dlhú históriu, poznačenú nejednou smutnou skutočnost'ou. O potenciály súčasnej netolerancie majority v kontexte Slovenska svedčí aj náš výskum. Skúmaná problematika naberá na vážnosti najmä ak si uvedomíme, že v oboch výskumných skupinách boli zaznamenané obdobné názory, ktoré charakterizuje výraznejšia negativita respondentov vo vzt’ahu k Židom na Slovensku; napriek malej osobnej skúsenosti s nimi.

Pozitívnym zistením je výrazný ústup negativizmu v skupine, hned’ po priznaní dobrej osobnej skúsenosti jedného z respondentov so židom. V skupine s výraznejšie negatívnym postojom respondentov k Židom (1 sk.) bolo zaznamenané úsilie respondentov hl'adat' pozitívne znaky kultúrnej a náboženskej odlišnosti.

\section{Záver}

V teoretickej časti príspevku sme poukázali na niekol'ko vybraných podôb netolerancie, ktoré obsahovali postoje Slovákov voči Židom pred komunizmom, počas neho a po ňom. Sústredili sme sa na dva vybrané aspekty netolerancie voči Židom, ktoré sa tiahnu všetkými sledovanými obdobiami - špecificky slovenský nacionalizmus ( $\mathrm{v}$ kontexte tzv. politického klerikalizmu) a židovský antisemitizmus.

Židovský antisemitizmus sa v troch obdobiach - pred komunizmom, počas neho a po komunizme - ukazuje ako univerzálny fenomén, tiahnuci sa naprieč generáciám Slovákov. Netolerancia majority voči židovskej minorite obsahuje aj prvky nacionaližmu, ktorý sprevádzajú výčitky majoritného obyvatel’stva voči židovskému spoločenskému, historickému aj náboženskému etnocentrizmu, odsudzovanie židovskej emancipácie, predsudky aj stereotypné obvinenia. Zdá sa, že netolerancia Slovákov má v troch sledovaných obdobiach okrem tradične náboženského charakteru i sekulárny, t.j. rasovo a etnicky zameraný ráz.

Vago si preto kladie zaujímavú otázku. Pýta sa, či sa netolerancia a židovský antisemitizmus stratia, ked' bude proces postkomunizmu na Slovensku nadobro ukončený. Podl’a autora sa to žial' neukazuje a antisemitizmus, definovaný ako najstaršia nenávist’ sa z nášho regiónu nestráca. Dôvodom podl’a Vaga je, že rozličné podoby antisemitizmu a extrémizmu sa u nás a rovnako aj v strednej a východnej Európe uskutočnovali ažptriliš dlho (Vago, 2000).

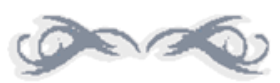

\section{Referencie:}

Budil, I.T. (2006). Totalitarismus v komparativní perpektivě: kritické reflexe. In: Budil, I.T. a Zíková, T. (2006). Totalitarismus 2. Ústí nad Labem: Vydavatel'stvo Vlasty Králové.

Fatranová, G. (2000). Životnost' antisemitských javov. In: Mešt’an, P. (Ed.). (2000). Acta Judaica

Slovaca, 6, 6, 161-176. Bratislava: Múzeum židovskej kultúry. 
Gallová-Kriglerová, E. et al. (2009). Kulturna rozmanitost’ a jej vnímanie žiakmi qákladných škôl na Slovensku. Bratislava: Nadácia otvorenej spoločnosti.

Gyárfášová, T. (2008). Faktory intergeneračného prenosu židovskej identity na Slovensku. In: Sociálni studia, 3-4, 179-192. Brno: Fakulta sociálních studií Masarykovy univerzity.

Hargašová, M. (1995). Tolerancia a intolerancia mládeže SR v skupinovom a interpersonálnom kontexte. In Mládę̌ a spoločnost', 1 (1), 14-31.

Hradská, K. (2014). Vzt’ah majority k židovskej menšine (nielen) v 19. storočí. In: Katolícka cirkev na Slovensku: Zborníky z konferencií [online]. Získané 10 októbra 2020 od https://www.kbs.sk/obsah/sekcia/h/dokumenty-a-vyhlasenia/p/zborniky-zkonferencii/c/bratislava-konferencia-kczi2014-06

Hradská, K. (2007). Reviz̧ioniz̧mus bolokaustu na Slovensku. In Nižňanský, E. (Ed). (2007). Z dejín bolokaustu a jeho popierania. Bratislava: Stimul.

Hrehová, H. (2009). Axiologicko-morálne premeny v Strednej Európe po roku 1990 a ich dopad na identitu človeka. In: Hrehová, H. et al. (Ed.). (2009). Transformácia liudskej identity v strednej Európe po roku 1990. Trnava: Filozofická fakulta.

Chudžíková, A. (2011). Muslims in Slovakia: Search for identity and status in majority society. In: Hunterová, H. \& Suchardová, J. (Eds.) (2011). Muslims in Visegrad. Prague: Institute of International Relations, 2011.

Inglehart, R., \& Baker, W. (2001). Modernization's Chalenge to Traditional Values. The Futurist, 3-4, 16-21.

Inštitút pre verejné otázky. (2018, 9 októbra). Zaostrené na extrémizmus. Výskumná štúdia. Získané 10 októbra 2020 od http://www.ivo.sk/8226/sk/aktuality/zaostrene-naextremizmus-vyskumna-studia

Kamenec, I. (2005). Holokaust na Slovensku, jeho reflexie v literatúre a spoločnosti. In: Terezínske listy, sborník památníku Terezín. Praha: Oswald.

Klein-Pejšová, R. (2010, 13 februára). Dejiny Židov na Slovensku. Získané 10 októbra 2020 od http://www.slovak-jewish-heritage.org/history-of-jews-in-slovakia.html?\&L=1

Krekovičová, E. a Panczová, Z. (2013). Obraz nepriatel’a v počiatkoch slovenskej politickej karikatúry: Vizuálne stereotypy v časopise Černokňažník v rokoch 1861-1910. Slovenský národopis, 61 (1), 31-54. Bratislava: Ústav etnológie a sociálnej antropológie Slovenskej akadémie vied.

Krivý, V. (2001). Hodnotové orientácie a náboženské prejavy slovenskej verejnosti v 90. Rokoch. In Sociológia, 33 (1), 7-45.

Kvasničková, A. (2005). Náboženstvo ako kolektivna pamät: prípad Slovenska a Ciech. Bratislava: Univerzita Komenského v Bratislave.

Macháček, L. (2007). Polarizácia politickej orientácie stredoškolákov na Slovensku. Slovenská politologická revue, VII. (4), 50-76.

Mešt’an, P. (2000). Niektoré špecifické podmienky reprodukcie negatívneho stereotypu Žida na Slovensku po roku 1989. Acta Judaica Slovaca, 6, 6, 177-190. Bratislava: Múzeum židovskej kultúry.

Orbanová, E. (2009). Pokles dominancie skupinovej identity z pohl’adu postmodernej religiozity. Transformácia l'udskej identity v strednej Európe po roku 1990. Trnava: Filozofická fakulta. 
Polonský, F., \& Novotný, J. (2011). The Level of Knowledge about Islam and Perception of Islam among Czech and Slovak University Students: Does Ignorance Determine Subjective Attitudes? Praha: Univerzita Karlova. (v angličtine)

Redakcia Aktuality.sk. (2016, 10 septembra). „Vermem si moslima.” Väčsina Slovákov by novinu

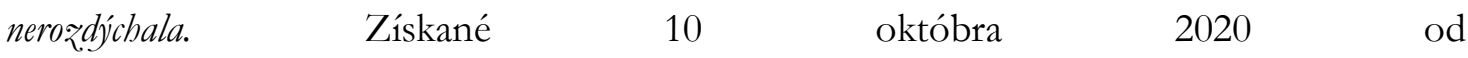
https://www.aktuality.sk/clanok/371480/vezmem-si-moslima-vacsina-slovakov-bynovinu-nerozdychala/

Redakcia samizdatu. (1988). Hlas Slovenska, 1. Získané 10 októbra 2020 od http://samizdat.sk/system/files/hlas-slovenska/1988/hlas-slovenska-1988-1.pdf\#page=3 Redakcia samizdatu. (1991a). Hlas Slovenska, 12. Archív Slovenskej národnej knižnice v Martine. Redakcia samizdatu. (1991b). Hlas Slovenska, 13. Archív Slovenskej národnej knižnice v Martine. TASR. (2018, 26 augusta). Antisemitizmu pribúda, tvrdí Gál po stretnutí s vel'vyslancom. Získané 10 októbra 2020 od https://www.parlamentnelisty.sk/politika/politicivolicom/Most-Hid-Antisemitizmu-pribuda-tvrdi-Gal-po-stretnuti-s-velvyslancom-304328 Vago, R. (2000). Antisemitizmus a politika v postkomunistickej strednej a východnej Európe. Acta Judaica Slovaca, 6, 6, 15-21. Bratislava: Múzeum židovskej kultúry.

Vagovič, M. (2012, 29 septembra). Deklarácia svedomia. Získané 10 októbra 2020 od https://www.tyzden.sk/casopis/12075/deklaracia-svedomia/

Vašečka, M. (2013). Sociologické aspekty xenofóbie. Cudrie nechceme, svoje si nedáme? Prekonávanie xenofóbie a antisemitižmu v náboženskéch textoch a praxi. Bratislava: Univerzita Komenského v Bratislave.

Vlach, J. (2006). Prenos hodnôt a medzigeneračné diferencie. Bratislava: Univerzita Komenského.

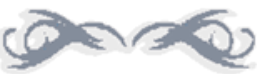

\section{Prílohy}

Tabul'ka 1. Charakteristika členov skupinového rozhovoru

\begin{tabular}{|c|c|c|c|}
\hline Skupina & Počet & Vek & Vzdelanie \\
\hline 1 skupina & 8 & $18-40$ & stredoškolské \\
\hline 2 skupina & 8 & $18-40$ & vysokoškolské \\
\hline
\end{tabular}

